\title{
EFFECTS OF GINGER AND BEE PROPOLIS ON THE PERFORMANCE, CARCASS CHARACTERISTICS AND BLOOD CONSTITUENTS OF GROWING JAPANESE QUAIL
}

\author{
H. S. Zeweil ${ }^{1}$, M. H. A. Abd El-Rahman ${ }^{1}$, W. M. Dosoky ${ }^{1}$, Salma H. Abu Hafsa ${ }^{2}$ and \\ A. B. A. Abdulhamid ${ }^{1}$ \\ ${ }^{1}$ Dep. of Anim. and Fish Prod., Fac. of Agric. (Saba Basha), Univ. of Alexandria, \\ Alexandria, Egypt \\ ${ }^{2}$ Dep.of Livestock Res., Arid Lands Cultivation Res. Instit., City of Scientific Res. and \\ Technological Applications, New Borg El-Arab, P.O. Box 21934, Alexandria, Egypt
}

Received: 18/ 11/2015

Accepted: 15/01/2016

\begin{abstract}
A B S T R A C T : This study was conducted to investigate the effect of supplementing ginger and bee propolis as a growth promoter and antioxidant material on performance traits, carcass characteristics, blood parameters and antioxidant status of growing Japanese quail. A total of one hundred and thirty-five, 7 days old unsexed growing Japanese quails were randomly divided into 5 groups, each 3 replication of 9 birds per replicate in a complete randomized design. Five diets were formulated as follows: the $1^{\text {st }}$ diet was basal diet without supplement and served as negative control and the $2^{\text {nd }}$ diet was basal diet supplemented with $100 \mathrm{mg} / \mathrm{kg}$ antibiotic and served as positive control, while the $3^{\text {rd }}$ and $4^{\text {th }}$ diets included $125 \mathrm{mg} / \mathrm{kg}$ ginger and $500 \mathrm{mg} / \mathrm{kg}$ bee propolis, respectively and the $5^{\text {th }}$ diet included a mixture of $125 \mathrm{mg}$ ginger $+500 \mathrm{mg}$ bee propolis/ $\mathrm{kg}$ diet. The results showed that dietary supplementations did not significantly $(\mathrm{P} \leq 0.05)$ influence the final live weight and weight gain. Significant $(\mathrm{P} \leq 0.05)$ decrease in feed intake was recorded in the group received antibiotic and $500 \mathrm{mg}$ propolis in their diet as compared to the control. Quails received 500 $\mathrm{mg}$ propolis in their diet had the best $(\mathrm{P} \leq 0.05)$ record of feed conversion ratio. This group surpassed the control one by $4.2 \%$. The highest value of relative carcass weights was obtained in the group received $500 \mathrm{mg}$ propolis $/ \mathrm{kg}$ diet. Numerical decrease was observed in relative weight of abdominal fat and numerical increase was observed in lymphoid organs in all groups fed the different supplementations. Antibody titters against avian Newcastle disease significantly improved by different treatments at 21 days after vaccination. Serum total lipids, triglycerides and total cholesterol were significantly decreased for groups fed on different feed additives as compared to negative control group. Significant increase in HDL concentration was recorded in the groups given ginger or propolis contained diets as compared to the control groups. Dietary treatments significantly increased total antioxidant capacity and glutathione peroxidase activity and significantly decreased Malondialdehyde compared to the negative control. In conclusion, the results indicated that growing Japanese quail fed diet supplemented with ginger, propolis or its combination could effectively be added to quail ration to improve feed conversion ratio and humeral immunity and optimize lipid profile in blood serum and enhance anti-oxidative status.
\end{abstract}

Key Words: Quail, Ginger, Bee propolis, Performance, Carcass, Blood constituents. 
Corresponding auther : hashim_salma@yahoo.com

\section{N T R O D U C T I O N}

Antibiotics are microbial metabolites produced by fungi and algae which have low molecule weight and can inhibit the growth of other microorganisms even in low concentrations (Nir and Ve-Senkoylu, 2000). While antibiotics have prevalently been used as growth promoters in animal nutrition, European Community has prohibited the use of antibiotics in animal nutrition as growth promoters from January 1, 2006. As a result of that, demands on alternative products have started. Consequently, studies on natural products such as plant extracts have recently gain a great attention (Wenk, 2000). It is stated that the phytoplankton can continuously be used in rations without any need for their removal and that they do not induce any resistance to antibiotics (Gill, 1999). At present, phytogenic products can be classified as sweeteners and appetizers without a requirement for the determination of their minimum residue levels (Kamel, 2002). On the other hand, there is misbelieve that "all plant extracts are beneficial since they are natural and organic". For example, the plant "EPHEDRA" was prohibited at the end of the year 2003 since it damages nervous system and leads psychosis, memory loss and even death. Animals, poultry in particular, are very sensitive to pathogenic bacteria such as E. coli, Salmonella sp. Clostridium perfringens and Campylobacter sputorum. The pathogenic microbial flora in the small intestine compete with host for nutrients while at the same time inhibiting the binding of the bile acids to the pertinent substances, they decrease the digestion of fats and fatsoluble vitamins. This leads to a decrease in performance and increase in disease rate. Antibiotics, which have been used as growth promoters in poultry feed for a long time, improve the growth performance by stabilizing the microbial flora in the intestine and preventing some specific intestine pathogens (Gunal et al., 2006). Another increasingly important recent natural product is propolis. It is a glue-like substance that honey bees collect from plant seedlings and buds. It is obtained as a result of the biochemical alteration of the resinous materials and plant secretions by the enyzmes secreted from the glands of the bees. It has a color ranging from dirty yellow to dark brown, a strong and nice odor, is water-insoluble and semi-solid in room temperature (Hepsen et al., 1996; Sahinler, 2000). The composition of raw propolis is generally composed of $50 \%$ resin and vegetal balsam, $30 \%$ bees wax, $10 \%$ essential and aromatic oils, $5 \%$ pollen and $5 \%$ other organic substances (Kumova et al., 2002; Dodologlu et al., 2003; Silici, 2003).

Ginger (Zingiber Officinale) is widely used in many countries as a food condiment and as a medicinal herb (Chrubasik et al., 2005). The main important compounds in Ginger are gingerol, gingerdioland gingerdione which have the ability to stimulate digestive enzymes, affect the microbial activity and having antioxidative activity (Dieumou $e t$ al., 2009). When used in broiler diets, ginger supplementation improved antioxidant and broiler chickens blood serum (Zhang et al., 2009). Ginger and propolis which could be considered as alternatives to antibiotics have a wide range of potential uses. Therefore, the determinations of the effects of these products on human and animal health are of significant importance at present due to the relation with safe nutrient production. Therefore, the objective of the present study was to determine the effect of propolis and ginger either as separate or in combination and their associated effects on growing Japanese quail performance, carcass traits, blood constituents, antioxidant status and immune response. 


\section{MATERIALS AND METHODS}

The present study was carried out at the Poultry Research Laboratory, Department of Animal and Fish Production, Faculty of Agriculture (Saba Basha), Alexandria University, Egypt. One hundred and thirtyfive, 7 days old unsexed growing Japanese quail chicks were randomly divided into 5 groups with 27 chicks in each group and each group was allotted into 3 replicates (9 each) in a complete randomized design. Five diets were formulated as follows: the $1^{\text {st }}$ diet was basal diet without supplement and served as negative control and the $2^{\text {nd }}$ diet was basal diet supplemented with $100 \mathrm{mg} / \mathrm{kg}$ antibiotic and served as positive control, while the $3^{\text {rd }}$ and $4^{\text {th }}$ diets included $125 \mathrm{mg} / \mathrm{kg}$ ginger and $500 \mathrm{mg} / \mathrm{kg}$ bee propolis, respectively and the $5^{\text {th }}$ diet included a mixture of $125 \mathrm{mg}$ ginger $+500 \mathrm{mg}$ bee propolis/ $\mathrm{kg}$ diet. The basal diet was formulated to meet the birds dietary nutrient requirements (NRC, 1994). The composition and chemical analyses of the basal diet is shown in Table 1. It contained $24 \%$ crude protein and 2900 Kcal ME/ Kg. Propolis obtained as powder from Egyptian market (HNBOOMBP-01, Code: 410004900, Henan Boom, China), also the ginger obtained from the local market. All quails were reared in wire batteries under the same managerial, hygienic and environmental conditions. Feed and water were available ad libitum. The house temperature was kept at about $35^{\circ} \mathrm{C}$ during the first 3 days, then gradually decreased by $2{ }^{\circ} \mathrm{C}$ weekly until reached $24^{\circ}$ $\mathrm{C}$ and kept constant until the end of the experiment. All birds were subjected to 23 hours light at intensity of $3 \mathrm{watt} / \mathrm{m}^{2}$ along the experimental period lasted for 28 days.
Live body weight, and weight gain and feed consumption of quails were recorded weekly. Feed conversion ratio was calculated (g feed / g gain). Six birds were randomly selected per treatment and fasted for $12 \mathrm{~h}$ before slaughtering to determine the carcass traits. Chick organs such as heart, liver, gizzard, abdominal fat and the lymphoid organs (thymus, spleen, pancreas and bursa) were weighed individually and expressed as percentage of slaughtered weight. Blood samples from the brachial vein of 4 birds in each treatment were drawn and serum were obtained by centrifugation of blood at 3500 r.p.m. for $15 \mathrm{~min}$. and kept at $-18{ }^{\circ} \mathrm{C}$ until analyzed. Serum total lipids, triglycerides, total cholesterol, low density lipoprotein (LDL), high density lipoprotein (HDL), Malondialdehyde (MDA), total antioxidant capacity and glutathione peroxidase activity were calorimetrically determined using commercial kits (Biomerieux, Poains, France). In a separate experiment, 40 unsexed growing quails, 7 days old were randomly divided into 5 groups with 8 quails in each group. All quails reared under the same experimental conditions in a separate building and fed the same experimental diets as shown previously for 42 day of age. On day 21 of age, 4 quails were randomly selected from each group and vaccinated with live-vaccine (HIB) via eye drop. After 14 and 21 of vaccination, quails from each group were bled via wing vein puncture using sterilized needle. The separated sera by centrifugation (4000 rpm, $15 \mathrm{~min}$ ) were used to assess the systemic antibody titer response to Newcastle disease virus (NDV). Antibodies to Newcastle Disease (ND) antigen in blood sera were measured by haemagglutination inhibition (HI) test as described by (Brown 
et al. 1990). Serial two fold dilutions of serum in $0.25 \mathrm{ml}$ amounts were prepared, equal amounts $(0.25 \mathrm{ml})$ of Newcastle disease virus (NDV) suspension containing 4 hemaglutinating (HA) units were then added to the serum dilutions. After mixing, the plates were left at room temperature for 10-15 minutes and then $0.25 \mathrm{rnl}$ amounts of $1 \%$ suspension of washed chicken red blood cells in saline was added. The plates were allowed to stand for 30 minutes at room temperature after which a serum titer was recorded as the highest serum dilution giving 50\% inhibition. Suitable serum, virus and red cell controls were included. The titers were transformed to $\log 2$ units and the log geometric mean (GM) of titers of a group of sera was calculated as following the method of Brown et al. (1990) to allow comparison.

Statistical analysis: Data were analyzed by one-way analysis of variance according to SAS (2004) and significant differences among means were detected by the Duncan's Multiple Range Test (Duncan, 1955).

\section{RESULTS AND DISCUSSION}

Results presented in Table (2) indicate that there were no significant differences in initial body weight among different treatments due to the random distribution of the experimental birds among treatments.

Dietary supplementations did not significantly $(\mathrm{P} \leq 0.05)$ influence the final live body weight and weight gain. This observation agreed with the results of ElDeek et al. (2002) who found that there were no significant differences in body weight by using 0.05 or $0.1 \%$ of ginger powder in broiler diets. Also, there was not improvement in body weight of broiler chicks fed $2 \%$ of dried ginger rhizomes supplement when compared to the chicks fed the control diet (Thayalini et al., 2011). Recently, Fakhim et al. (2013) found that body weight gain of the chickens was not significantly different among the birds fed diets contained ginger supplements and control. Also, Silici et al. (2007) reported that propolis had no detrimental effect on the health but did not improve the performance parameters of quail in the first 35 days of age. Mahmoud et al. (2013) observed that addition of 100, 250, 500 and $750 \mathrm{mg} / \mathrm{kg}$ propolis did not improve broiler performance. Kleczek et al. (2014) found that the final body weight of broiler chickens during the rearing period did not significantly differ between groups given diets contained antibiotic, propolis and control diets. Contrary to all these studies, there are positive effects of ginger plant extracts and/or propolis on live body weight gain (Hernandez et al., 2004; Roodsari et al., 2004; Shalmany and Shivazad, 2006). Supplementing diet with ginger meal resulted in a better growth performance, as shown by the improvement in body weight of broiler chicks (Ademola et al., 2009; Zhang et al., 2009). On the other hand, Santos et al. (2003) reported that propolis decreased live body weight gain of growing broilers during 42 days. Acikgos et al. (2005) indicated that supplementation of male broiler chicks with $4000 \mathrm{ppm}$ propolis significantly decreased body weight. Moreover, KoyaMiyata et al. (2009) recorded that administration of $50 \mathrm{mg} / \mathrm{kg}$ propolis extract orally in mice significantly reduced the weight gain.

The results in Table (2) showed a significant $(\mathrm{P} \leq 0.05)$ decrease in feed intake for groups received antibiotic and $500 \mathrm{mg}$ propolis in their diet as compared with the control group. The decrease in these groups reached to 2.1 and $3.4 \%$, respectively. The lowest value in feed intake was recorded in the group given $500 \mathrm{mg}$ propolis in their diet as compared with the other experimental groups. Mahmoud et al. (2013) who found insignificant reduction in 
feed intake in propolis treated groups. Kleczek et al. (2014) found that the feed intake $(\mathrm{kg})$ per $\mathrm{kg}$ body weight of broiler chickens was not significantly different between the groups given diets contained antibiotic, propolis or control diets during the rearing period. Also, the finding of Acikgoz et al. (2005) and Canogullari et al. (2009) indicated that the dietary supplementation with propolis had no significant effect on average daily feed consumption when compared with the control group. While, Silici et al. (2007) reported that, propolis had no detrimental effect on the health but did not improve the performance parameters of quails in first 35 days. Controversially, It was observed that feed intake was significantly increased when quails fed on propolis (Denli et al., 2004), and broilers (Biavatti, et al., 2003; Ziaran et al., 2005; Shalmany and Shivazad, 2006; Hassan and Abdulla, 2011 and Daneshmand et al., 2012). Concerning ginger, Barazesh et al. (2013) when fed Ross chicks on diets contained different levels of ginger powder $(0,0.5,1$ and 1.5 $\%$ ), observed that increasing levels of dietary ginger powder caused a significant reduction in feed intake, and the lowest feed intake and the best feed conversion ratio values were recorded in the group fed $1 \%$ ginger powder as compared to the control and the other experimental groups.

Significant $(\mathrm{P} \leq 0.05) \quad$ differences among different treatments and control group were found in feed conversion ratio. The birds received $500 \mathrm{mg}$ propolis in their diet had the best record of feed conversion ratio. This group surpassed the control one by 4.2 $\%$. The other experimental groups showed insignificant effect in feed conversion ratio in comparison with the control group. Generally, the decrease in feed intake and improvement in feed conversion ratio may be due to the presence of phenolis and flavonoids ofpropolis supplementation which could be attributed to their antimicrobial, antioxidant activity and improving nutrient utilization (Tatli Seven et al., 2009). Haro et al. (2000) mentioned that propolis improved feed conversion ratio which depended on the fact that digestive functions are favored by this dietary supplement.

The effect of treatments on digestibility coefficients of nutrients is shown in Table (3). The different supplementations had insignificant effect on digestibility of crude protein, ether extract, crude fiber, organic matter and nitrogen free extract. Most of feed additives used in the present study showed insignificant improvement in digestibility coefficients of most nutrients as compared to those of the control groups. Synergistic effect due to the combination of propolis and ginger powders did not give any advantage over that presented with each of propolis or ginger alone. Ginger has been shown to contain a high level of plant proteolytic enzyme (Thompson et al., 1973; Ziauddin et al., 1995) that could help birds digest dietary protein upon ingestion. Also Rao et al. (2003) found that ginger enhanced the activity of pancreatic chymotrypsin and amylase. They reported also that the positive influence on the activity of enzymes may have a supplementary role in the overall digestive stimulant action of ginger, besides causing an enhancement of titres of digestive enzymes in pancreatic tissue. Incharoen and Yamauchi (2009) found that the rhizome of ginger can stimulate digestive juices such as bile, salivary, gastric, pancreatic and intestinal secretions. Acikgos et al. (2005) reported that dry matter and organic matter digestibilities did not change in both starter and grower diets supplemented by propolis of broilers, whereas propolis supplementation to the starter diet improved the digestibility of ether extract $\quad(\mathrm{P} \leq 0.05)$. However, consuming propolis for the first three weeks had adverse effect on crude protein digestibility of broilers in the subsequent three weeks $(\mathrm{P} \leq 0.05)$. Also, da Silva et al. (2014) reported that lambs given propolis in their diet did not affect dry matter, 
organic matter, crude protein digestibility, but crude propolis supplementation provided higher ether extract digestibility than monensin sodium.

Supplementation of different feed additives to Japanese quail diets significantly $(\mathrm{P} \leq 0.05)$ affected the relative carcass weight (Table 4). The highest value of relative carcass weight was obtained from the group received $500 \mathrm{mg}$ propolis/ $\mathrm{kg}$ diet. This group surpassed the control by $3.3 \%$ with insignificant differences as compared to the control group. However, the lowest value was recorded in the group fed a mixture of ginger and propolis with insignificant differences among these groups. Anitibiotic and ginger supplementation gave an equal effect to the control group. A mixture of ginger and propolis recorded a significant $(\mathrm{P} \leq 0.05)$ less relative carcass weight than propolis inclusion. The different supplementations did not significantly affect the relative weight of liver, heart, gizzard and pancreas. However, numerical decrease was observed in relative weight of abdominal fat in all groups fed the different supplementations. The lowest value in abdominal fat content was recorded by birds received antibiotic, followed by mixture of ginger and propolis, respectively. Kleczek et al. (2014) reported that the broiler chickens carcass weight did not differ significantly between broilers groups fed diets contained antibiotic, propolis or control group. Coloni et al. (2006) showed that propolis extract $(0,0.8$ and $1.5 \mathrm{ml})$ did not affect $(\mathrm{P}>0.05)$ carcass edible organs relative weights of growing NZW rabbits slaughtered at $84 \mathrm{~d}$ of age, and carcass and inner organs weights of broiler chicks (Tekeli et al., 2011).

It is clear as presented in Table (5) that the relative weight of bursa of fabricious was increased in birds fed diets contained 500 mg propolis as compared to the control and the other experimental groups. Most of the experimental feed additives showed an increase in relative weight of thymus and spleen as compared with the control group. The increase in lymphoid organs weight may be an adaptive response to feed additives administration. Results in Table (5) showed that using different feed additives in the present study had insignificant increase in antibody titters against NDV at 14 days after vaccination. While, at 21 days after vaccination, antibody titters against NDV were significantly increased in all treated groups compared to the control groups. The mixture of ginger and porpolis was superior in antibody titters against NDV at 21 days after vaccination followed by propolis treatment then ginger treatment, respectively.

The increase in lymphoid organs weight may be connected to the effect of feed additives on lymphatic organs activities. The impact of these feed additives as an immune-stimulant in quail could be attributed to several possibilities: an enhancement of lymphocyte activation or proliferation, or an increased life time span of the lymphocytes, or a combination of these mechanisms. Therefore, it could be assumed that the enhancement of the humeral immunity in the present study could be related to the elevation of the lymphatic organs activities. Consequently, it could be recommended that modulation of the immune status of young quail may produce beneficial effects and provide a new avenue in improving poultry production.

The effect of different feed additives on meat quality index such as water holding capacity (WHC), $\mathrm{pH}$, color, tenderness and its chemical composition (dry matter, crude protein, ether extract and ash) were not significantly affected by different treatments as compared to the control group (Table 6).

Results Table (7) showed that most of different supplementations induced a 
significant $(\mathrm{P} \leq 0.05)$ decrease in serum total cholesterol, total lipids and triglycerides for groups fed on different feed additives as compared to quails fed negative control diet. Significant $(\mathrm{P} \leq 0.05)$ increase in HDL concentration was recorded in the groups given ginger or propolis contained diets as compared to quails fed control diets. Significant decrease in LDL concentration was recorded in the groups given ginger, ropolis or their combination in diets compared to negative control group. The decrease in triglycerides and cholesterol may be attributed to propolis that plays a major role as antioxidant material which increased glutathione enzyme activity. Propolis contains some components such as essential fatty acids which inhibit hepatic 3-hydroxy-3-methylglutaryl coenzyme A (HMG-CO A) reductase activity (Crowell, 1999) which is a key regulatory enzyme in cholesterol synthesis. These results are in agreement with those obtained by Babaei et al. (2004) who reported that Japanese quail fed diet contained $1000 \mathrm{ppm}$ alcoholic extract of propolis significantly $(\mathrm{P} \leq 0.05)$ lowered total cholesterol, triglycerides and LDL and increased level of HDL in the blood as compared with quail fed control diet. It was expressed in the findings of diverse studies that propolis intake lead to a decrease in the level of plasma triglycerides concentration (Fuliang et al., 2005). This lowering effect can be attributed to the regulatory mechanism of the flavanoids as one of the ingredients in these natural products for blood circulation and stimulation of triglycerids use for energy generation (Tekeli et al., 2011). On the other hand, Daneshmand et al. (2015) reported that propolis supplementation in broiler chicks diet resulted in insignificant differences with regard to serum lipid profile as compared with control. Regarding to ginger, Onu and Aja (2011) reported that the hypocholesterolemic effect of ginger could have possibly resulted from the inhibition of cellular cholesterol biosynthesis. The adding ginger rhizome powder to the food could be useful in the management of cardiovascular disease in which atherosclerosis is the most important factor may be due to the presence polyphenolis and flavonoids may prevent coronary artery disease by reducing plasma cholesterol level or by inhibiting LDL oxidation, a process which is through to play a key role in the pathogenesis of atherosclerosis (Bordia et al., 1997; Fuhrman et al., 2000; Nicoll and Henein, 2009).

The different dietary treatments significantly $(\mathrm{P} \leq 0.05) \quad$ increased total antioxidant capacity and glutathione peroxidase activity and significantly $(\mathrm{P} \leq 0.05)$ decreased MDA compared to the negative control group (Table 8). This increase of total antioxidant capacity and glutathione peroxidase in serum indicated that all feed additives used in the present study improved the antioxidant status in growing Japanese quail. The best values of total antioxidant capacity were recorded in the group received the mixture of ginger and propolis followed by groups received $500 \mathrm{mg}$ propolis, ginger $125 \mathrm{mg} / \mathrm{kg}$ and $100 \mathrm{mg}$ antibiotic, respectively. Malondialdehyde as an indicator of lipid peroxidation and oxidative stress was significantly decreased in all treatments compared to the negative control. Flavonoids from propolis have been reported to elevate glutathione peroxidase, catalase, superoxide dismutase and mRNA synthesis by increasing the activities of antioxidant enzymes, also flavonoids from propolis reduce the number of free radicals or ROS generated and increase the production of molecules protecting against oxidative stress (Jeon et al., 2002). Propolis and its polyphenolic and flavonoid components increased the activities of glutathione peroxidase, superoxide dismutase, catalase, glutathione reductase and glutathione (Molina et al., 2003; Orsolic and Basic, 2005). Several flavonoids have been reported to protect against DNA damage (Russo et al., 2000). 
Ginger has been defined as an important component of an antioxidant network that prevents membrane damage from oxidation (Hui, 1996 and Akhani et al., 2004).

\section{CONCLUSION}

Bee propolis, ginger or their mixture could effectively be used as a growth promoter and natural antioxidant in growing Japanese quail diets for improving feed conversion ratio, humeral immunity and to optimize lipid profile in blood serum and enhance anti-oxidative status without negative effects on birds viability. 
Table (1): Composition and chemical analysis of the basal experimental diets

\begin{tabular}{|l|c|}
\hline \multicolumn{1}{|c|}{ Ingredients } & \% \\
\hline Yellow corn & 53.30 \\
Soybean meal (44 \%) & 33.00 \\
Concentrate $(50 \%) *$ & 10.00 \\
Di-calcium phosphate & 0.20 \\
Limestone & 1.70 \\
Sunflower oil & 0.80 \\
Vit. and min. mix.** & 0.50 \\
Salt (NaCl) & 0.50 \\
& \\
\hline Total & 100 \\
\hline Calculated analyses ${ }^{1:}$ & \\
\hline Crude protein, \% & 24.05 \\
ME (Kcal/ Kg diet) & 2907.10 \\
Ether extract, \% & 2.44 \\
Crude fiber, \% & 3.63 \\
Methionine, \% & 0.76 \\
Methionine + cysteine, \% & 0.88 \\
Lysine, \% & 1.42 \\
Calcium, \% & 1.11 \\
Av. phosphorus & 0.39 \\
\hline
\end{tabular}

* Concentrate : $\mathrm{ME}(\mathrm{K} \mathrm{cal} / \mathrm{kg}) 2870$, Crude protein 50\%, Crude fiber $1.51 \%$, Crude fat $54.1 \%$ Calcium 29.4\%, Phosphorus 39.2\%, $\mathrm{NaCl} 8.0 \%$, Methionine 6.4\%, Methionine \&Cysteine $38.5 \%$, Lysine $90.3 \%$.

** Each $\mathrm{kg}$ of vitamin and minerals mixture contained: Vit. A, 4,000,000 IU; Vit. $\mathrm{D}_{3}, 500,000 \mathrm{IU}$; Vit, E, 16.7 g., Vit. K, 0.67 g., Vit. B1, 0.67 g., Vit. B2, 2 g., Vit. B 6, .67 g., Vit. B12, 0.004 g., Nicotinicacid, 16.7 g., Pantothenicacid, 6.67 g., Biotin, 0.07 g., Folicacid, 1.67 g., Choline chloride, 400 g., Zn, 23.3 g., Mn, 10 g., $\mathrm{Fe}, 25$ g., Cu, 1.67 g., I, 0.25 g.,Se, 0.033 g. and,Mg, 133.4 g.

${ }^{1}$ According to NRC (1994). 
Table (2): Effect of ginger, bee propolis and their mixture on productive performance of growing Japanese quail.

\begin{tabular}{|c|c|c|c|c|c|}
\hline Treatments & $\begin{array}{c}\text { Initial } \\
\text { body } \\
\text { weight }(\mathbf{g})\end{array}$ & $\begin{array}{c}\text { Final body } \\
\text { weight }(\mathbf{g})\end{array}$ & $\begin{array}{c}\text { Weight gain } \\
(\mathbf{g})\end{array}$ & $\begin{array}{c}\text { Feed intake } \\
(\mathbf{g})\end{array}$ & $\begin{array}{c}\text { Feed } \\
\text { conversion } \\
\text { ratio }\end{array}$ \\
\hline Negative control & $30.02 \pm 0.46$ & $225.43 \pm 3.08$ & $195.41 \pm 3.07$ & $464.66 \pm 2.53^{\mathrm{a}}$ & $2.38 \pm 0.01^{\mathrm{ab}}$ \\
Positive control & $30.0 \pm 0.46$ & $227.64 \pm 3.81$ & $197.56 \pm 3.73$ & $454.82 \pm 3.29^{\mathrm{bc}}$ & $2.30 \pm 0.03^{\mathrm{bc}}$ \\
$125 \mathrm{mg}$ ginger (G) & $30.03 \pm 0.47$ & $221.58 \pm 2.59$ & $191.55 \pm 2.51$ & $458.53 \pm 2.70^{\mathrm{abc}}$ & $2.39 \pm 0.02^{\mathrm{a}}$ \\
500 mg propolis (P) & $30.01 \pm 0.44$ & $227.44 \pm 3.63$ & $197.43 \pm 3.49$ & $449.32 \pm 2.46^{\mathrm{c}}$ & $2.28 \pm 0.02^{\mathrm{c}}$ \\
$\begin{array}{c}\text { Combination of G }+ \\
\text { P }\end{array}$ & $29.99 \pm 0.45$ & $222.14 \pm 3.18$ & $197.42 \pm 3.09$ & $457.67 \pm 2.50^{\mathrm{abc}}$ & $2.32 \pm 0.02^{\mathrm{abc}}$ \\
\hline
\end{tabular}

a - c: different superscripts within a column indicate significant differences $(\mathrm{P} \leq 0.05)$.

Table (3): Effect of ginger, bee propolis and their mixture on digestibility coefficients of nutrients of growing Japanese quail.

\begin{tabular}{|l|l|l|l|l|l|}
\hline Treatments & $\begin{array}{l}\text { Crude } \\
\text { protein } \\
\text { \% }\end{array}$ & $\begin{array}{l}\text { Ether } \\
\text { extract } \\
\text { \% }\end{array}$ & $\begin{array}{l}\text { Crude } \\
\text { Fiber } \\
\text { \% }\end{array}$ & $\begin{array}{l}\text { Nitrogen } \\
\text { free extract } \\
\text { \% }\end{array}$ & $\begin{array}{l}\text { Organic } \\
\text { matter } \\
\text { \% }\end{array}$ \\
\hline Negative control & $82.93 \pm 0.68$ & $80.85 \pm 0.76$ & $13.17 \pm 3.44$ & $74.59 \pm 1.01$ & $73.99 \pm 1.03$ \\
Positive control & $84.12 \pm 0.57$ & $82.18 \pm 0.64$ & $19.22 \pm 2.92$ & $76.36 \pm 0.85$ & $75.80 \pm 0.87$ \\
125 mg ginger (G) & $84.77 \pm 2.93$ & $82.91 \pm 3.29$ & $22.51 \pm 14.90$ & $77.32 \pm 4.36$ & $76.79 \pm 4.46$ \\
500 mg propolis (P) & $85.33 \pm 0.84$ & $83.55 \pm 0.95$ & $25.38 \pm 4.29$ & $78.16 \pm 1.26$ & $77.65 \pm 1.29$ \\
Combination of G + P & $83.84 \pm 0.34$ & $81.88 \pm 0.38$ & $17.82 \pm 1.74$ & $75.95 \pm 0.51$ & $75.38 \pm 0.52$ \\
\hline
\end{tabular}

Table (4): Effect of ginger, bee propolis and their mixture on carcass traits of growing Japanese quail.

\begin{tabular}{|l|l|l|l|c|c|c|}
\hline \multicolumn{1}{|c|}{ Treatments } & Carcass \% & Liver\% & Heart \% & $\begin{array}{c}\text { Gizzard } \\
\text { \% }\end{array}$ & $\begin{array}{c}\text { Pancreas } \\
\text { \% }\end{array}$ & $\begin{array}{c}\text { Abdominal } \\
\text { fat \% }\end{array}$ \\
\hline $\begin{array}{l}\text { Negative control } \\
\text { Positive control }\end{array}$ & $65.94 \pm 0.24^{\mathrm{ab}}$ & $2.12 \pm 0.28$ & $0.81 \pm 0.04$ & $1.78 \pm 0.11$ & $0.22 \pm 0.04$ & $0.97 \pm 0.09$ \\
$\begin{array}{l}125 \mathrm{mg} \text { ginger (G) } \\
500 \text { mg propolis }\end{array}$ & $65.62 \pm 0.87^{\mathrm{abc}}$ & $2.49 \pm 0.39$ & $0.88 \pm 0.10$ & $1.83 \pm 0.10$ & $0.21 \pm 0.03$ & $0.54 \pm 0.16$ \\
$\begin{array}{l}\text { (P) } \\
\begin{array}{l}\text { Combination of G } \\
+P\end{array}\end{array}$ & $64.65 \pm 0.36^{\mathrm{bc}}$ & $2.37 \pm 0.33$ & $0.82 \pm 0.12$ & $2.01 \pm 0.24$ & $0.22 \pm 0.05$ & $0.66 \pm 0.14$ \\
\hline
\end{tabular}

a - c: different superscripts within a column indicate significant differences $(\mathrm{P} \leq 0.05)$. 
Table (5): Effect of ginger, bee propolis and their mixture on lymphoid organs and humeral immunity of growing Japanese quail.

\begin{tabular}{|c|c|c|c|c|c|}
\hline \multirow[b]{2}{*}{ Treatments } & \multirow{2}{*}{$\begin{array}{c}\text { Bursa of } \\
\text { fabricious, } \\
\%\end{array}$} & \multirow{2}{*}{$\begin{array}{c}\text { Thymos, } \\
\%\end{array}$} & \multirow{2}{*}{$\begin{array}{c}\text { Spleen, } \\
\%\end{array}$} & \multicolumn{2}{|c|}{ Humeral immunity } \\
\hline & & & & at 14 day & at 21 day \\
\hline Negative control & $0.93 \pm 0.01$ & $0.101 \pm 0.01$ & $0.036 \pm 0.00$ & $1.00 \pm 0.00$ & $2.0 \pm 0.00^{d}$ \\
\hline Positive control & $0.101 \pm 0.02$ & $0.136 \pm 0.02$ & $0.055 \pm 0.01$ & $1.00 \pm 0.00$ & $2.0 \pm 0.00^{\mathrm{d}}$ \\
\hline 125 mg ginger $(\mathrm{G})$ & $0.92 \pm 0.00$ & $0.137 \pm 0.03$ & $0.053 \pm 0.01$ & $1.33 \pm 0.67$ & $2.50 \pm 0.03^{c}$ \\
\hline $500 \mathrm{mg}$ propolis $(\mathrm{P})$ & $0.141 \pm 0.02$ & $0.117 \pm 0.01$ & $0.045 \pm 0.01$ & $1.67 \pm 0.33$ & $3.50 \pm 0.13^{b}$ \\
\hline $\begin{array}{l}\text { Combination of } \mathrm{G}+ \\
\mathrm{P}\end{array}$ & $0.094 \pm 0.02$ & $0.182 \pm 0.01$ & $0.047 \pm 0.01$ & $1.33 \pm 0.33$ & $4.50 \pm 0.00^{\mathrm{a}}$ \\
\hline
\end{tabular}


Table (6): Effect of ginger, bee propolis and their mixture on chemical analyses of meat and physical characteristics of meat at 5 weeks of age

\begin{tabular}{|c|c|c|c|c|c|c|c|c|}
\hline \multirow{2}{*}{ Treatments } & \multicolumn{4}{|c|}{ Chemical analyses of meat, \% } & \multicolumn{4}{|c|}{ Meat physical characteristics } \\
\hline & Dry matter & Protein & Fat & Ash & pH & Color & WHC & Tenderness \\
\hline Negative control & $28.81 \pm 0.21$ & $21.75 \pm 0.26$ & $3.20 \pm 0.10$ & $3.39 \pm 0.39$ & $6.76 \pm 0.17$ & $0.38 \pm 0.17$ & $9.33 \pm 1.59$ & $6.01 \pm 1.59$ \\
\hline Positive control & $29.84 \pm 0.21$ & $22.40 \pm 0.27$ & $3.35 \pm 0.13$ & $3.65 \pm 0.07$ & $7.17 \pm 0.12$ & $0.24 \pm 0.04$ & $9.71 \pm 0.05$ & $5.72 \pm 0.54$ \\
\hline 125 mg ginger $(\mathrm{G})$ & $29.39 \pm 0.56$ & $21.86 \pm 0.26$ & $3.45 \pm 0.11$ & $3.62 \pm 0.55$ & $6.57 \pm 0.20$ & $0.23 \pm 0.04$ & $10.73 \pm 0.17$ & $7.42 \pm 0.37$ \\
\hline $500 \mathrm{mg}$ propolis $(\mathrm{P})$ & $28.34 \pm 0.43$ & $21.74 \pm 0.34$ & $2.90 \pm 0.11$ & $3.21 \pm 0.23$ & $6.57 \pm 0.02$ & $0.23 \pm 0.02$ & $9.22 \pm 0.40$ & $5.49 \pm 0.30$ \\
\hline $\begin{array}{l}\text { Combination of } \mathrm{G}+ \\
\mathrm{P}\end{array}$ & $28.52 \pm 0.30$ & $21.65 \pm 0.16$ & $3.39 \pm 0.08$ & $3.02 \pm 0.47$ & $6.90 \pm 0.32$ & $0.23 \pm 0.01$ & $9.28 \pm 1.15$ & $5.14 \pm 1.25$ \\
\hline
\end{tabular}

Table (7): Effect of ginger, bee propolis and their mixture on blood serum lipid profile

\begin{tabular}{|c|c|c|c|c|c|}
\hline Treatments & $\begin{array}{l}\text { Total lipids } \\
\text { (mg/dl) }\end{array}$ & $\begin{array}{l}\text { Triglycerides } \\
\text { (mg/dI) }\end{array}$ & $\begin{array}{c}\text { Cholesterol } \\
\text { (mg/dI) }\end{array}$ & $\begin{array}{c}\text { HDL } \\
/(\mathbf{m g} / \mathbf{d I})\end{array}$ & $\begin{array}{c}\text { LDL } \\
(\mathrm{mg} / \mathrm{dI})\end{array}$ \\
\hline Negative control & $1011.50 \pm 40.23^{\mathrm{a}}$ & $467.50 \pm 1.85^{\mathrm{a}}$ & $259.50 \pm 19.85^{\mathrm{a}}$ & $19.75 \pm 0.25^{b}$ & $165.45 \pm 19.12^{\mathrm{a}}$ \\
\hline Positive control & $668.50 \pm 6.80^{\mathrm{e}}$ & $232.50 \pm 1.89^{\mathrm{d}}$ & $205.50 \pm 2.90^{\mathrm{b}}$ & $17.75 \pm 0.48^{b}$ & $141.25 \pm 2.66^{\mathrm{ab}}$ \\
\hline 125 mg ginger $(\mathrm{G})$ & $683.50 \pm 10.07^{\mathrm{de}}$ & $220.50 \pm 4.29^{\mathrm{d}}$ & $219.00 \pm 2.92^{\mathrm{b}}$ & $25.00 \pm 0.71^{\mathrm{a}}$ & $135.25 \pm 1.89^{\mathrm{b}}$ \\
\hline $500 \mathrm{mg}$ propolis $(\mathrm{P})$ & $792.50 \pm 17.73^{c}$ & $340.00 \pm 20.41^{c}$ & $213.75 \pm 2.78^{b}$ & $23.25 \pm 0.48^{\mathrm{a}}$ & $122.50 \pm 6.61^{\mathrm{b}}$ \\
\hline Combination of $\mathrm{G}+\mathrm{P}$ & $855.75 \pm 12.34^{b}$ & $424.75 \pm 2.21^{\mathrm{b}}$ & $191.00 \pm 5.21^{\mathrm{c}}$ & $24.00 \pm 1.58^{\mathrm{a}}$ & $110.00 \pm 3.49^{c}$ \\
\hline
\end{tabular}

a - d: different superscripts within a column indicate significant differences $(\mathrm{P} \leq 0.05)$. 
Table (8): Effect of ginger, bee propolis and their mixture on serum antioxidative Status in Japanese quail

\begin{tabular}{|l|l|l|l|}
\hline Treatments & $\begin{array}{l}\text { Total } \\
\text { antioxidant } \\
\text { capacity }(\mathbf{m m} / \mathbf{L})\end{array}$ & $\begin{array}{l}\text { Glutathione } \\
\text { peroxidase }(\mathbf{m u} / \mathbf{m l})\end{array}$ & $\begin{array}{l}\text { Malondialdehyde } \\
(\mathbf{n m o l} / \mathbf{m l})\end{array}$ \\
\hline Negative control & $0.66 \pm 0.02^{\mathrm{c}}$ & $15.55 \pm 0.47^{\mathrm{b}}$ & $14.89 \pm 0.33^{\mathrm{a}}$ \\
Positive control & $1.38 \pm 0.06^{\mathrm{a}}$ & $29.44 \pm 0.38^{\mathrm{a}}$ & $11.64 \pm 0.23^{\mathrm{b}}$ \\
$125 \mathrm{mg}$ ginger (G) & $1.38 \pm 0.06^{\mathrm{a}}$ & $28.40 \pm 0.26^{\mathrm{a}}$ & $11.22 \pm 0.02^{\mathrm{b}}$ \\
$500 \mathrm{mg}$ propolis $(\mathrm{P})$ & $1.42 \pm 0.13^{\mathrm{a}}$ & $27.95 \pm 0.11^{\mathrm{a}}$ & $9.62 \pm 0.10^{\mathrm{c}}$ \\
Combination of G + & $1.45 \pm 0.02^{\mathrm{a}}$ & $28.76 \pm 0.40^{\mathrm{a}}$ & $9.04 \pm 0.25^{\mathrm{c}}$ \\
$\mathrm{P}$ & & & \\
\hline
\end{tabular}

a - d: different superscripts within a column indicate significant differences $(P \leq 0.05)$.

\section{REFERENCES}

Acikgoz, Z., B. Yucel and O. Altan (2005). The effects of propolis supplementation on broiler performance and feed digestibility. European Poultry Science 69, 117-122.

Ademola, S. G., G. O. Farinu and G. M. Babatunde (2009). Serum lipid growth and haematological parameters of broilers fed garlic, ginger and their mixture. World Journal of Agricultural Sciences 5(1): 99-104.

Akhani, S. P., S. L. Vishwakarma and R. K. Goyal (2004). Anti-diabetic activity of Zingiber officinale in Streptozotocininduced type I diabetic rats. J. of Pharmacy and Pharmacal, 56: 101-105.

Babaei, S., S. Rahimi, M. A. KarimiTorshizi, N. KhaleghiMiran, G. A. Nehzati and N. Razmgah (2004). Effects of propolis, honey, royal jelly, and bee pollen on the growth performance and blood parameters of quail (Coturnix coturnix japonica). Poult. Sci. (E-suppl.1): 389 P.

Barazesh, H., M. B. Pour, S. Salari and T. M. Abadi (2013). The effect of ginger powder on performance, carcass characteristics and blood parameters of broilers. International journal of Advanced Biological and Biomedical Research Volume 1 (1). 1645-1651.

Biavatti, M.W., M.H. Bellaver, L. Volpato, C. Costa and C. Bellaver
(2003). Preliminary studies of alternative feed additives for broilers: Alternantherabrasiliana extract, propolis extract and linseed oil. Rev. Bras. Cienc. Avic. 5(2): 147-151.

Bordia, A., S. Verma and K. Srivastava (1997). Effects of ginger and fenugreek on blood lipids, blood sugar and platelet aggregation in patients with coronary artery disease. Prostaglandins, Leukotrienes and essential fatty acids, 56: 379-384.

Brown, J.; R. S. Resurrection and T. G. Dickson (1990). The relationship between the hemagglutionationinhibition test and the enzyme-linked immunosorbent assay for the detection of antibody to Newcastle disease. Avian Dis. 34, (3), 585-587.

Canogullari, S., M. Baylan, NuraySahinler and A. Sahin (2009). Effects of propolis and pollen supplementations on growth performance and body components of Japanese quails (Coturnixcoturnix japonica). Arch. Geflügelk., 73 (3). S. 173-178.

Chrubasik, S., M. H. Pittlerand B. D. Roufogalis (2005). Zingiber is rhizoma: Acomprehensive review on the ginger effect and efficacy profiles. Phytomedicine. 12 (9):684-701.

Coloni, R. D., E. Santos, M. C. Oliveira, A. C. Neto, E. B. Malheiros and E. P. Filho (2006). Effect of oral 
administration of propolis alcoholic extract on the carcass of growing rabbits. Abstracts of the $3^{\text {rd }}$ Rabbit Congress of TheAmercas, Maringa, Parana, Brazil, August, 21-23.

Crowell, P.L. (1999). Prevention and therapy of cancer by dietary monoterpenes. J. Nutr., 129: 775S-778S.

Daneshmand, A., G. H. Sadeghi, A. Karimi, A. Vaziry and S.A. Ibrahim (2015). Evaluating complementary effects of ethanol extract of propolis with the probiotic on growth performance, immune response and serum metabolites in male broiler chickens. Livestock Science 178: 195201.

Daneshmand A., G. H. Sadeghi and A. Karimi (2012). The effects of a combination of garlic, oyster mushroom and propolis extract in comparison to antibiotic on growth performance, some blood parameters and nutrients digestibility of male broiler. Br. J. Poult. Sci. 14(2): 141-147.

da Silva, J. A., , C. C. B. F. Ítavo, L. C. V. Ítavo, M. Morais, G. L. Franco, L. M. Zeoula and N. Heimbach (2014). Effects of dietary brown propolis on nutrient intake and digestibility in feedlot lambs. R. Bras. Zootec. vol.43 no.7 Viçosa July 2014.

Denli, M., F. Okan and A. N. Uluocak (2004). Effect of dietary supplementation of herb essential oils on the growth performance, carcass and intestinal characteristics of quail (Coturnix coturnix japonica). South African Journal of Animal Science 34: 79-85.

Dieumou, F.E., A. Teguia, J.R. Kuiate, J.D.Tamokou, N.B. Fonge, and M.C. Dongmo (2009). Effects of ginger (Zingiber Officinale) and garlic (Allium sativum) essential oils on growth performance and gut microbial population of broiler chickens. Livestock Research for Rural Development.21: 2534.
Dodologlu, A., S. Kutlucaand F. VeGene (2003). Production and Use of Propolis II Proceedings of the Marmara Apiculture Congress, April 28-30, Yalova, Turkey, pp:184-192.

El-Deek, A. A., Y. A. Attea, M. Maysa and M. Hannfy (2002). Effect of anise (Pimpinellaanisumii), ginger (Zingiber officinale Roscoe) and fennel (Foeniculumvulgare) and their mixture on performance of broilers. Arch. Geflugelkd, 67: 92-96.

Fakhim, R., Y. Ebrahimnezhad, H. R. Seyedabadi and T. Vahdatpour (2013). Effect of different concentrations of aqueous extract of ginger (Zingiber officinale) on performance and carcass characteristics of male broiler chickens in wheatsoybean meal based diets. J. Bio Sci. Biotech. 2013, 2(2): 95-99.

Fuhrman, B., M. Rosenblat, T. Hayek, R. Coleman and M. Aviram (2000). Ginger extract consumption reduces plasma cholesterol, inhibits LDL oxidation and attenuates development of atherosclerosis in atherosclerosis in atherosclerotic apolipo protein Edeficient mice. J. Nutr., 130(5): 11241131.

Fuliang, H. U., H. R. Hepburn and H. Xuan (2005). Effects of propolis on blood glucose, blood lipid and free radicals in rats with Diabetes mellitus. Pharmacol Res, 51, 147-152.

Gill, C. (1999). Herbs and plant extracts as growth enhancers. Feed Int., 202023.

Greathead, H. (2003). Plants and plant extracts for improving animal productivity. Proc. Nutr. Soc., 62, 279-290. Gunal, M., G. Yayli, 0. Kaya, N. Karahanand 0. Sulak (2006). The effects ofantibiotic growth promoter, probiotic or organic acid supplementation on performance, intestinal microflora and tissue of broiler. Int. J. Poult. Sci. 5:149-155. 
Haro, A., I. Lopez-Aliaga, F. Lisbona, M. Barrionuevo, M. J. Alferez and M. S. Campos (2000). Beneficial effect of pollen and/or propolis on the metabolism of iron, calcium, phosphorus and magnesium in rats with nutritional ferropenic anemia. Journal of Agricultural and Food Chemistry 48, 5715-5722.

Hassan, M.G. and T. A. Abdulla (2011). The effect of propolis feed supplementation on hygiene and performance of broiler chickens. Iraqi Journal of Veterinary Science 25, 77-82.

Hepsen, I. F., F. Tilgen and E. Hamdi (1996). Propolis: Medical properties and uses of talmolojic. Turgut Ozal Center Med., J., 3: 386-391.

Hernandez, F., J. Madrid, V. Garcia, J. Orengo and M.D. Megias (2004). Influence of two plant extracts on broiler performance, digestibility and digestive organ size. Poult. Sci., 83: 169-174.

Hui, Y. H. (1996). Oleoresins and essential oils. In: Hui Y. H. editor, Bailey's industrial oil and fat products. New York: Wiley-intersciences publication. Pp 145-153.

Incharoen, T. and K. Yamauchi (2009). Production performance, egg quality and intestinal histology in laying hens fed dietary dried fermented ginger. International Journal of Poultry Science, 8 (11), 1078-1085.

Jeon S. M., S. H. Bok M. K. Jang Y. H. Kim K. T. Nam T. S. Jeong Y. B. Park and M. S. Choi (2002). Comparison of antioxidant effects of naringin and probucol in cholesterol-fed rabbits. Clin. Chim. Acta., 317: 181-190.

Kamel, C. (2002). Farm to fork strategy for added value Int. Poultry Prod., 10: 18-21.

Kleczek, K, E. Wawro, K. Wawro, W. Makowski, D. Murawska and $M$. Wawro (2014). The effect of dietary propolis supplementation on the growth performance of broiler chickens. Pol. J. Natur. Sc., Vol 29(2): 105-117.
Koya-miyata, S., N. Aria, A. Mizote, Y. Taniguchi, S. Ushio, K. Iwaki and S. Fukuda (2009).Propolis prevent diet induced hyperlipidemia and mitigates weight gain in diet induced obesity in mice. Biological and Pharmaceutical Bulletin 32: 2022-2028.

Kumova, U., A. Korkmaz, B. C. Avci and G. Ceyran (2002). Propolis: An important bee product. Uludag Bee $\mathbf{J}$., 2:10-24.

Mahmoud, U. T., M. A. Abdel-Rahman and Madeha H. A. Darwish (2013). The Effect of Chinese Propolis Supplementation on Ross Broiler Performance and Carcass Characteristics. Journal of Advanced Veterinary Research Vol. 3: 154-160.

Malekizadeh , M, M. M. Moeini and S. H. Ghazi (2012). The effects of different levels of ginger (Zingiber Officinale Rescoe) and Turmeric (Curcuma longa Linn) Rhizomes powder on some blood metabolites and production performance characteristic of Laying Hens. J. Agr., Sci. Tech., 14: 127-134.

Molina, M. F., I. Sanchez-Reus, I. Iglesias and J. Benedi (2003). Quercetin, a flavonoid antioxidant, prevents and protects against ethanolinduced oxidative stress in mouse liver. Biol Pharm Bull. 26(10):1398-402.

Nicoll, $R$ and M. Y. Henein (2009). Ginger (ZingiberOffecinale Roscoe): a hot remedy for cardiovascular disease. In. J. cardiol., 131: 408- 409.

Nir, I. and N. Ve-Senkoylu (2000).Supporter Feed Additive for Poultry Digestive. Roche Ltd,UK.

NRC (1994). Nutrient requirements of poultry $\left(9^{\text {th }}\right.$ ed.). National Academy Press, Washington D.C., USA.

Onu P. N and P. M. Aja (2011). Growth performance and haematological indices of weaned rabbits fed garlic (Allium sativum) and ginger (Zingiber officinale) supplemented diets. International 
Journal of Food, Agriculture and Veterinary Sciences Vol. 1 (1): 51-59.

Orsolic, N. and I. Basic, (2005). "Immuno-modulation by watersoluble derivatives of propolis: a factor of antitumour reactivity," Journal of Ethnopharmacology, vol. 84, no. 2-3, pp. 265-273.

Rao, R. R., K. Platel and K. Srinivasan (2003). In vitro influence of spices and spice-active principles on digestive enzymes of rat pancreas and small intestine. Molecular Nutrition and Food Research; 47(6): 408-412.

Roodsari, M. H., M. Mehdizadeh, F.B. Kasmani, H. Lotfelahian, F. Mosavi and A. H. Abolghasemi (2004). Effects of oil-extracted propolis on the performance of broyler chicks. Agric. Sci. Technol., 18: 57-65. SAS, 1987.

Russo, A., R. Acquaviva, A. Campisi, V. Sorrenti, C. Di Giacomo, G. Virgata, M. L. Barcellona and A. Vanella (2000). Bioflavonoids as antiradicals, antioxidants and DNA cleavage protectors. Cell. Biol. Toxicol., 2000; 16: 91-98.

Sahinler, N. (2000). Bee products and its importance on account of human health. Mustafa KemalUniv,Fac. Agric.J., 5:139-148.

Santos, A.V., A. S. Teixeira, P. B. Rodrigues, R. T. F. Freitas, A. M. Guimaraes and R. A. Giacometti (2003). Nutritive value of propolis residue for broiler chickens. Ciencia e Agrotecnologia, 27, 1152-1159.

SAS Institute. (2004). SAS User's Guide: Statistics. Edition 9.1. SAS Institute Inc., Cary, NC.

Shalmany, S. and M. Shivazad (2006). The effect of diet propolis supplementation on ROSS broiler chicks performance. International Journal of Poultry Science 5: 84-88.

Silici, S., M. Uenlue and G. VardarUenlue (2007). Antibacterial activity and phytochemical evidence for the plant origin of Turkish propolis from different regions. World Journal of Microbiology and Biotechnology, New York, Vol. 23 (12): 1797-1803.

Silici, S. (2003). A research on some antimicrobial and pharmacological properties of propolis. Ph.D. Thesis, University of Cukurova, Institute of Natural and Applied Sciences, Department of Animal Science, Adana.

Tatli Seven, P., S. Yılmaz, I. Seven, I. H. Çerçi, M. A. Azman and M. Yılmaz (2009). The effect of propolis on selected blood indicators and antioxidant enzyme activities in broilers under heat stress. Acta Vet Brno, 78: 75-83.

Tekeli, A., H. R. Kutlu and L. Celik (2011). Effects of $Z$. officinale and propolis extracts on the performance, carcass and some blood parameters of broiler chicks. Current Research in Poultry Science, 1(1):12-23.

Thayalini, K., S. Shanmugavelu, P. M. Saminathan, M. S. SitiMasidayu, Y. Nor Idayusni, H. Zainuddin, C. A. NurulAkmal, and H. K. Wong (2011). Effects of cymbopogoncitratus leaf and zingiber officinale rhizome supplementation on growth performance, ileal morphology and lactic acid concentration in broilers. Malaysian Journal of Animal Science. 14:43-49.

Thompson, E. H., I. D. Wolf, and C. E. Allen (1973). Ginger rhizome: A new source of proteolytic enzyme. J. Food Sci. 38:652-655.

Wenk, C. (2000). Why all the discussion about herbs? Biotechnolgy in the feed industry. Proceedings of Alltech's $16^{\text {th }}$ A nnual Sympsium, (AAS'OO), Alltech Technical Puplications, Nottingham Universty Press, Nicholasville, KY, pp: 79-96.

Zhang, G. F., Z. B. Yang, Y. Wang, W. R. Yang, S. Z. Jiang and G. S. Gai (2009). Effects of ginger root (Zingiber officinale) processed to different particle sizes on growth performance, 
antioxidant status, and serum metabolites of broiler chickens. Poultry Science, 88: 2159-2166.

Ziaran, H.R., H.R. Rahmani and J. Pourreza (2005). Effect of dietary oil extract of propolis on immune response and broiler performance. Pak. J. Biol.

Ziauddin, S. K., D. N. Rao, and B. L. Amla (1995). Effect of lactic acid, ginger extract and sodium chloride on electrophoretic pattern of buffalo muscle proteins. Journal of Food Science and Technology. 32: $224-226$.

Sci., 8: 1485-1490.

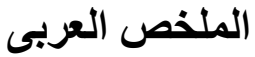

$$
\begin{aligned}
& \text { تأثير إضافه الزنجبيل وبروبوليس نحل العسل علي الأداء الإنتاجي وصفات الأبيحه ومكونات الدم } \\
& \text { للسمان الياباني }
\end{aligned}
$$

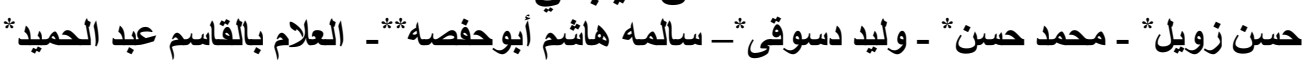

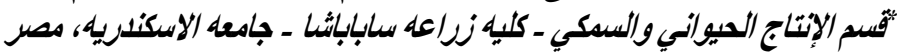

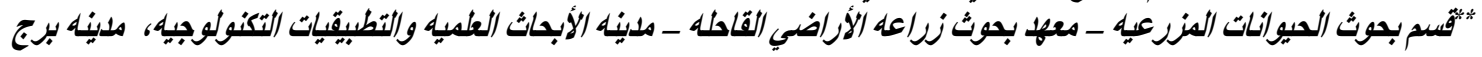

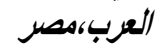

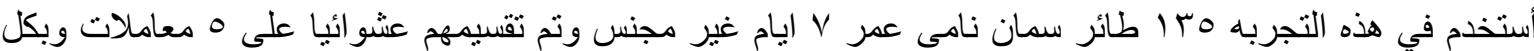

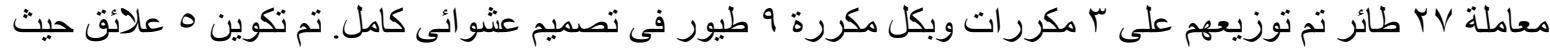

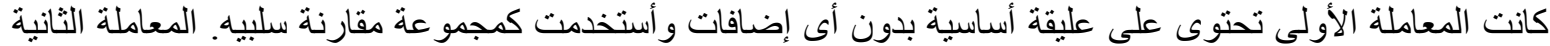

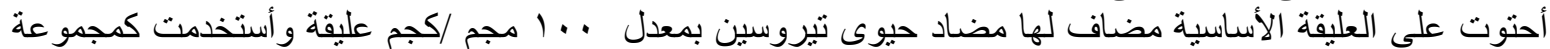

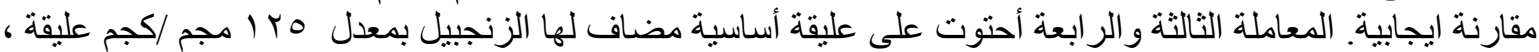

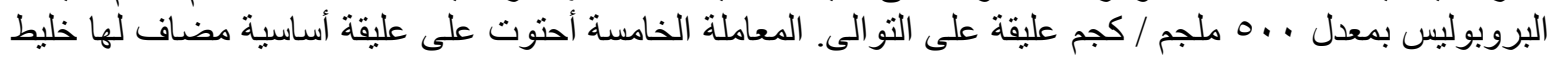

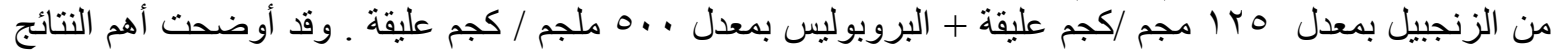

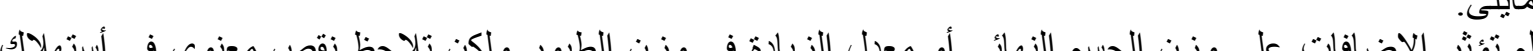

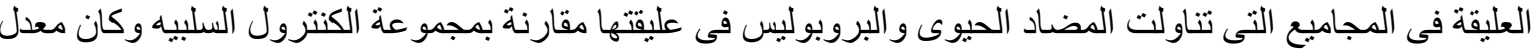

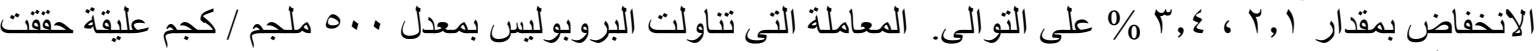

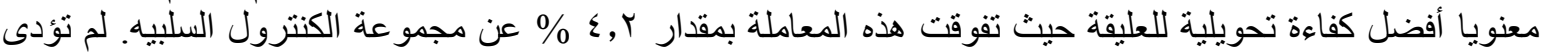

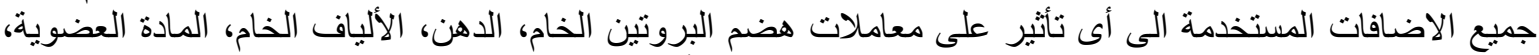

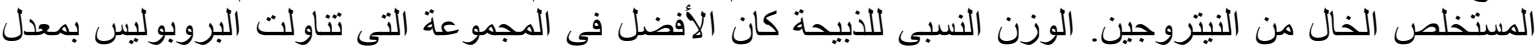

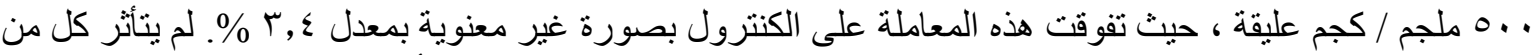

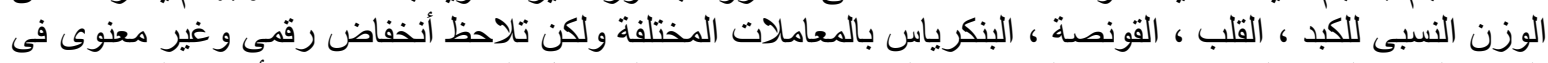

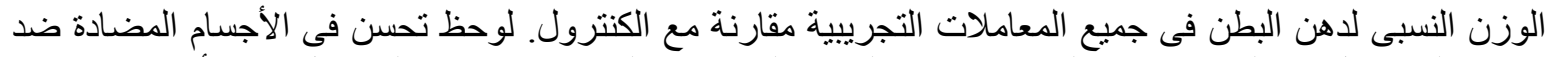

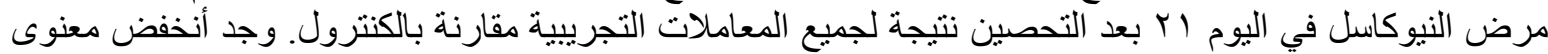

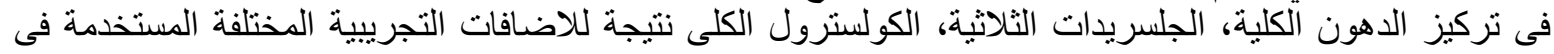

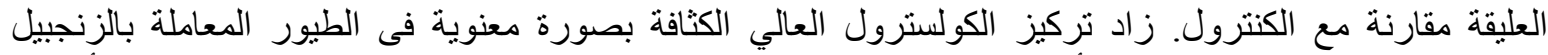

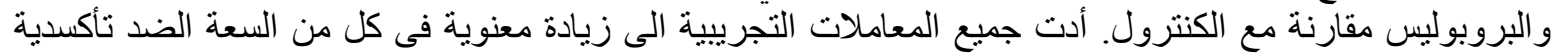

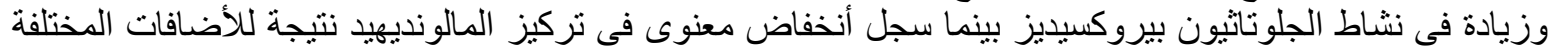

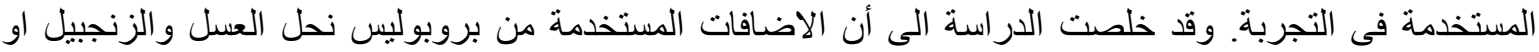

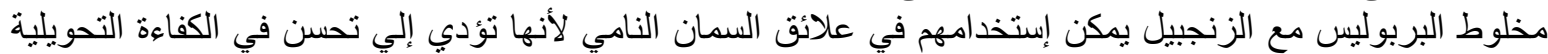
و الصفات المناعية وخفض مستوى الدهون فى سيرم دم الطيور وتحسين الصفات الضئ الضد نأكسدية. 